\title{
Faktor - faktor Penentu Keberhasilan Perencanaan Asuhan Keperawatan
}

\author{
Winda Sari Sinaga \\ Windasarisng1701@gmail.com
}

\section{Latar Belakang}

Asuhan keperawatan merupakan proses yang menjadi suatu rangkaian kegiatan pada praktik keperawatan yang diberikan secara langsung kepada klien atau pasien. Asuhan keperawatan dilakukan berdasarkan kaidah-kaidah keperawatan sebagai suatu profesi yang berdasarkan ilmu dan kaidah keperawatan, yang bersifat humanistik dan berdasarkan kebutuhan objektif klien. Dimana bertujuan untuk mengatasi masalah yang sedang dihadapi klien. Proses keperawatan dalam asuhan keperawatan juga berfungsi untuk memberikan kemampuan kepada perawat dalam memberi asuhan keperawatan kepada klien termasuk dalam pemecahan masalah yang dialami. Semua tahapan dalam asuhan keperawatan penting untuk diperhatikan dan dilakukan dengan baik oleh perawat. Salah satunya ialah tahapan perencanaan asuahan keperawatan atau intervensi keperawatan.

Perencanaan keperawatan merupakan tindakan yang dilakukan perawat untuk meningkatkan status kesehatan pasien menjadi lebih baik dari sebelumnya. Pada perencanaan keperawatan inilah yang menjadi tahapan untuk perumusan suatu masalah yang mencakup kepada keluhan klien atas masalah yang sedang di hadapinya. Gunanya untuk menentukan suatu perencanaan asuhan keperawatan yang akan melengkapi suatu proses dari keperawatan, perawat harus mampu menetapkan rencana tindakan keperawatan yang akan dilakukan/ diberukan untuk mengatasi masalah pada klien. Pedoman intervensi ini dibuat secara tersurat, terstruktur dan terencana secara baik dan matang berdasarkan hasil dari perumusan dari aspek keperawatan atau hasil kolaborasi dari bidang lainnya yang akan ditegakkan dan dilakukan dalam implementasi keperawatan. Intervensi keperawatan menjadi salah satu hal yang wajib didokumentasikan secara lengkap juga dengan guna dalam pertukaran shift keperawatan, agar memudahkan perawat yang 
bertugas selanjutnya untuk mengetahui perencanaan terhadap pasien serta memberikan kebutuhan jangka panjang perawat.

Pada tahapan intervensi keperawatan, perawat dituntut harus mampu untuk merumuskan, menentukan serta menetapkan prioritas dalam menangani masalah masalah yang dihadapi klien. Peran perawat sangat penting dalam pelaksanaan intervensi keperawatan, yang mana intervensi yang telah ditetapkan akan diimplementasikan kepada klien. Maka diperlukan perencanaan atau intervensi yang benar. Banyak hal yang menjadi faktor yang menentukan keberhasilan dari perencanaan atau intervensi yang telah dibuat atau yang akan dibuat oleh perawat. Aspek - aspek itulah yang dapat mempengaruhi dari intervensi yang akan dibuat, maka dari itu seorang perawat dituntut untuk menambah pengetahuannya dalam menentukan perencanaan asuhan keperawatan. Dengan mengetahui hal-hal yang menjadi faktor penentu yang mendukung keberhasilan dari perencanaan asuhan keperawatan yang ditentukan.

\section{Metode}

Metode yang digunakan oleh penulis dalam jurnal ini adalah Literature review, dengan cara membaca, menganalisis bahan kajian yang relavan dengan pokok bahasan yakni mengenai faktor - faktor penentu keberhasilan perencanaan asuhan keperawatan.

Dimana dengan membaca beberapa jurnal dan bahan kajian terkait lainnya, kemudian menyusun kalimat sendiri yang selanjutnya dituliskan untuk menyelesaikan literature review ini. Bahan kajian yang digunakan yakni berupa textbook, e-book, buku pedoman terkait, tesis dan

jurnal online. Adapun jurnal dan referensi yang digunakan pada literature review ini, diterbitkan paling lama tahun 2012, dengan jumlah minimal yaitu 10 referensi.

\section{Hasil}

Berdasarkan hasil dari pencarian dan pengkajian literature dari berbagai sumber, didapatkan bahwa terdapat adanya hubungan dan pengaruh pelaksanaan komponen asuhan keperawatan dengan keberhasilan perencanaan keperawatan dan adanya hubungan dan kaitan 
pendidikan dan pengetahuan perawat dengan keberhasilan dari rencana keperawatan yang telah ditetapkan.

Komponen tahapan asuhan keperawatan merupakan faktor pendukung dan penentu keberhasilan dari perencanaan asuhan keperawatan. Dimana kelima tahapan asuhan keperawatan tersebut saling berkaitan dan berhubungan satu dengan yang lainnya. Intervensi atau perencanaan asuhan keperawatan dapat dilakukan apabila tahapan komponen asuhan keperawatan sebelumnya sudah dilaksanakan dengan baik, hal inilah yang menjadi faktor yang mendukung dan mempengaruhi hasil dari intervensi yang ditetapkan.

Adapun tahapan sebelumnya yang harus dilakukan sebelum menetapkan perencanaan keperawatan ialah melakukan pengkajian dan menetapkan diagnosa keperawatan, setelah komponen dan tahapan tersebut dilakukan dengan data yang sudah didapatkan kemudian perawat dapat menyusun, merumuskan dan menetapkan intervensi asuhan keperawatan. Hasil dari perencanaan atau intervensi keperawatan akan diimplementasikan kepada klien. Yang kemudian akan dievaluasi dan disurvei untuk meningkatkan keberhasilan perencanaan di waktu mendatang.

Dari Jurnal Gambaran Tingkat Pengetahuan Perawat Dalam Penerapan Standar Asuhan Keperawatan Diruangan Rawat Inap Interna RSUD Datoe Bhinangkang (2015), berdasarkan hasilnya dapat disimpulkan bahwa adanya hubungan yang signifikan terkait pengetahuan dan pendidikan perawat dengan keberhasilan dari perencanaan asuhan keperawatan yang ditetapkan. Dimana perawat yang memiliki pengetahuan yang baik, perawat yang memiliki masa kerja yang lama akan mempengaruhi dari hasil perencanaan asuhan keperawatan yang perawat tersebut tetapkan.

Pada Tesis Analisis Penerapan Standar Asuhan Keperawatan di Ruang Rawat Inap Rumah Sakit Umum Provinsi Sulawesi Tenggara (2012), berdasarkan hasilnya dapat disimpulkan bahwa pentingnya menerapkan dan pelaksanaan prosedur asuhan keperawatan, yang mana hal ini akan berpengaruh terhadap banyak aspek yakni kesembuhan pasien, kepuasan pasien, keselamatan, kesehatan dan keamanan pasien. Pada jurnal ini membahas mengenai pelaksanaan prosedur asuhan keperawatan, dimana perawat dan proses keperawatan ditunjukkan bahwa pengetahuan, pendidikan, motivasi, dan persentase perawat mempengaruhi teknik dan bagaimana perawat tersebut bekerja. Dalam membuat suatu rencana tindakan keperawatan, diperlukan perawat yang 
memiliki pengetahuan yang luas mengenai berbagai aspek dalam keperawatan. Perawat dengan tingkat pengetahuan yang tinggi akan lebih mudah merancang perencanaan tindakan keperawatan.

\section{Pembahasan}

Perencanaan merupakan proses penyusunan berbagai intervensi keperawatan yang di butuhkan untuk mencegah atau mengurangi masalah-masalah klien. Perencanaan keperawatan merupakan tahap yang dilakukan setelah pengkajian dan penentuan diagnosa keperawatan. Keterkaitan antara setiap tahapan komponen asuhan keperawatan sangat berpengaruh terhadap tahapan selanjutnya. Perawat tidak dapat melakukan perencanaan tindakan keperawatan apabila tidak melaksanakan terlebih dahulu tahapan asuhan keperawatan sebelumnya, yakni melakukan pengkajian dan menetapkan diagnosa keperawatan.

Perencanaan keperawatan dilaksanakan sesuai dengan penentuan prioritas diagnosa, penentuan tujuan dan hasil yang di harapkan sesuai intervensi keperawatan yang telah di tetapkan. Perencanaan keperawatan juga merupakan petunjuk tertulis yang menggambarkan secara tepat mengenai rencana tindakan yang dilakukan terhadap pasien sesuai dengan tingkat kebutuhan berdasarkan diagnosa keperawatan yang muncul. Untuk itu, rencana tindakan yang baik tentunya haruslah berdasarkan pada diagnosa keperawatan yang telah dirumuskan Intervensi keperawatan menjadi panduan untuk perilaku spesifik yang diharapkan dari klien, dan/atau tindakan yang harus dilakukan oleh perawat. Intervensi dilakukan untuk membantu klien mencapai hasil yang diharapkan.

Perencanaan keperawatan yang dilakukan terhadap klien harus sesuai dengan kebutuhannya, yang berdasarkan kepada diagnosa keperawatan. Untuk menetapkan keberhasilan dalam perencanaan asuhan keperawatan, harus melibatkan orang terdekat maupun orangtua dari klien untuk merumuskan suatu masalah yang dihadapi klien. Dalam merencanakan intervensi keperawatan, perawat harus memperhatikan beberapa kriteria yang terkait dengan rumusan intervensi keperawatan. Kriteria pertama dari perumusan intervensi keperawatan ialah menetapkan hasil perencanaan secara logis dan sesuai dengan prioritas yang akan dilaksanakan. Kriteria kedua dari perumusan intervensi keperawatan ialah hasil perencanaan harus bersifat spesifik, dimana didalam asuhan keperawatan, kriteria haruslah menyangkut kepada permasalahan utama yang 
dialami klien dimana masalah prioritas tersebut merupakan masalah yang paling utama yang wajib untuk diberikan intervensi keperawatan. Apabila hasil dari perencanaan keperawatan telah sesuai kriteria dari perumusan intervensi keperawatan, maka selanjutnya rencana tindakan keperawatan dapat diimplementasikan kepada klien. Hasil dari rencana tindakan keperawatan ini selanjutnya akan dilakukan atau diimplementasikan kepada klien sesuai kebutuhan klien, yang kemudian akan dievaluasi dan disurvei apakah rencana tindakan keperawatan yang telah diimplementasikan tersebut berhasil atau tidak. Melalui tahapan setelah intervensi keperawatan yakni, evaluasi keperawatan akan dilakukan survei terkait keseluruhan penerapan prosedur asuhan keperawatan yang telah diterapkan, guna untuk meningkatkan keberhasilan perencanaan di waktu mendatang.

Pada dasarnya perencanaan asuhan keperawatan merupakan suatu proses penyusunan berbagai intervensi keperawatan yang dibutuhkan untuk mencegah, menurunkan atau mengurangi masalah-masalah klien. Dalam menentukan dan menetapkan intervensi keperawatan, seorang perawat dituntut untuk memiliki berbagai pengetahuan dan keterampilan. Perawat harus mampu mengaplikasikan pengetahuannya dan harus mampu untuk melakukan tindakan keperawatan. Perawat harus mengetahui dan menerapkan pengetahuannya mengenai analisis identifikasi kekuatan dan kelemahan klien, nilai dan kepercayaan klien, batasan praktek keperawatan, peran dari tenaga kesehatan lainnya, kemampuan dalam memecahkan masalah, mengambil keputusan, menulis tujuan serta memilih dan membuat strategi keperawatan yang aman dalam memenuhi tujuan, menulis instruksi keperawatan serta kemampuan dalam melaksanakan kerja sama dengan tingkat kesehatan lain.

Pengetahuan, pendidikan dan lama masa kerja perawat merupakan salah satu elemen yang berpengaruh dan meniadi faktor penentu dari keberhasilan perencanaan asuhan keperawatan yang perawat buat dan tetapkan. Berdasarkan hasil penelitain pada sumber referensi, perawat yang memiliki sikap dan pengetahuan yang baik, akan melakukan perencanaan keperawatan setelah melakukan tahapan pengkajian dan telah menetapkan diagnosa keperawatan dari klien. Tingkat pengetahuan perawat memiliki pengaruh terbesar dengan kelengkapan dan ketepatan perawat dalam melaksanakan tindakan asuhan keperawatan. Perawat dengan pengetahuan yang baik, dan perawat dengan masa kerja yang lama atau perawat yang sudah berpengalaman memiliki presentasi ketepatan dan keberhasilan rencana tindakan keperawatan diatas $75 \%$, yang dapat 
diartikan bahwa perawat dengan pengetahuan yang baik, dan perawat yang sudah berpengalaman memiliki presentasi keberhasilan rencana tindakan keperawatan yang baik.

Pada intervensi keperawatan independen, perawat dituntut untuk melakukan tindakan yang bermakna yang dapat dilakukanya tanpa ada bantuan dari pihak lain atau tenaga kesehatan lainnya. Namun untuk mendapatkan hasil yang maksimal dalam perencanaan keperawatan yang mana nantinya akan menjadi dasar tindakan atau implementasi asuhan keperawatan yang kemudiannya akan diterapkan pada pasien, perawat perlu dan harus melakukan perencanaan atau intervensi kolaboratif. Pada intervensi kolaboratif, rencana tindakan keperawatan yang dilakukan oleh perawat terhadap klien dalam bentuk kerja sama dengan tenaga kesehatan lain. Perawat harus melakukan kerjasama dengan profesi tenaga kesehatan yang lain untuk menciptakan kualitas layanan yang prima maka. Untuk menetapkan suatu diagnosa medis, perawat harus bekerjasama dengan dokter untuk menetapkan diagnosa tersebut terlebih dahulu agar kiranya capaian yang akan dilakukan berjalan dengan maksimal.

Perawat juga harus terampil dan mampu menerapkan pengetahuannya dalam melaksanakan semua aspek tindakan yang akan dilakukan kepada pasien. Dalam melakukan perencanaan keperawatan, perawat harus tahu bagaimana harusnya bersikap, mengambil tindakan dan menguasai diri dalam melakukan proses keperawatan yang bertahap. Dimana segala proses harus melalui tahapan yang baik dan benar.

Perawat harus mampu dalam pendelegasian dan mempertimbangkan bagaimana seharusnya tindakan yang akan diberikan kepada pasien. Hal ini dalam merencankan suatu asuhan keperawatan, haruslah dilihat dari sudut pandang penyakit atau patofisiologi dari penyakit tersebut, keyakinan serta kebiasaan dari pasien, jangan sampai tindakan yang dilakukan perawat melanggar budaya ataupun norma dari klien tersebut. Maka dari itu, perawat harus mampu memperhatikan segala aspek yang ada pada diri kliennya. Sehingga dapat disimpulkan bahwa perawat yang dengan pengetahuan dan pendidikan yang baik dapat membuat perencanaan asuhan keperawatan yang baik. Dan perawat dengan pengetahuan yang baik akan mengikuti dengan terbentuknya seorang perawat yang memiliki sikap dan perilaku yang baik dalam bekerja sama untuk mencapai dan merencanakan intervensi asuhan keperawatan. 


\section{Penutup}

Keterkaitan antara pengetahuan dan pendidikan perawat terhadap ketepatan dan keberhasilan perencanaan keperawatan menjadi faktor yang berpengaruh besar dan menjadi penentu keberhasilan perencanaan atau intervensi keperawatan yang ditetapkan perawat. Perawat yang dengan pengetahuan dan pendidikan yang baik dapat membuat perencanaan asuhan keperawatan yang baik. Pengalaman kerja perawat yang sudah lama dan berpengalaman juga mempengaruhi ketepatan perawat dalam membuat suatu rencana tindakan keperawatan. Dan dimana perawat dengan pengetahuan yang baik akan mengikuti dengan terbentuknya seorang perawat yang memiliki sikap dan perilaku yang baik dalam bekerja sama untuk mencapai dan merencanakan intervensi asuhan keperawatan.

Perencanaan keperawatan hasus dilaksanakan sesuai dengan penentuan prioritas diagnosa, penentuan tujuan dan hasil yang di harapkan sesuai intervensi keperawatan yang telah di tetapkan. Maka dari itu, pentingnya penerapan pelaksanaan prosedur asuhan keperawatan yang lengkap dan benar, dimana untuk dapat menetapkan rencana tindakan keperawatan haruslah terlebih dahulu perawat melakukan tahapan prosedur pengkajian dan menetapkan diagnosa keperawatan.

\section{Daftar Pustaka}

Achmadi, L. D., Pondaag, L., \& Babakal, A. (2015). Gambaran Tingkat Pengetahuan Perawat dalam Penerapan Standar Asuhan Keperawatan di Ruangan Rawat Inap Interna RSUD Datoe Bhinangkang. Jurnal Keperawatan. 3 (3): 1-3.

Astar, Fatmawati, dkk. (2018). PENGARUH PELAYANAN ASUHAN KEPERAWATAN TERHADAP KEPUASAN PASIEN DI PUSKESMAS TAKALALA KABUPATEN SOPPENG. Journal stieamkop MIRAI : JOURNAL OF MANAGEMENT. 1 ( 2) : 33-57.

Nurlina, dkk. (2013). Faktor - Faktor Yang Berhubungan dengan Penerapan Standar Asuhan Keperawatan Di Ruang Rawat Inap RSUD Labuang Baju Makassar. Journal Univeristas Negri Makassar. 7 ( 4 ).

Wirdah Husnul, Yusuf Muhmmad. (2016). Penerapan Asuhan Keperawatan oleh Perawat Pelaksana di Rumah Sakit Banda Aceh. Jurnal Ilmu Keperawatan unsyiah. 1 (1) : 1-7. 
Sari, N. P. W. P., Fernatubun, J. F. D., Mare, Y. B., Fi, S. N. (2016). Literature review: Intervensi keperawatan terkini untuk meningkatkan pengetahuan dan tindakan masyarakat dalam pencegahan pengendalian malaria. Jurnal Hesti WIra Sakti: Fakultas Keperawatan Universitas Katolik Widya Mandala. 4 (1) : 76-93.

Siswanto, L.M. Harmain, dkk. (2013). Faktor Faktor yang Berhubungan dengan Kelengkapan Pendokumentasian Asuhan Keperawatan. Jurnal Keperawatan Indonesia. 16 (2) : 77-84.

Aini, D. N. (2018). Hubungan Kualitas Pelayanan Keperawatan dengan Tingkat Kepuasan Pasien Rawat Inap di RSUD DR. H. SOEWONDO KENDAL. Jurnal Ners Widya Husada. 5 (2) : 49-58.

Butar-Butar, J., \& Simamora, R. H. (2016). Hubungan Mutu Pelayanan Keperawatan dengan Tingkat Kepuasan Pasien Rawat Inap di RSUD Pandan Kabupaten Tapanuli Tengah. Jurnal Ners Indonesia, 6(1), 50-63.

Simamora, R. H. (2005). Hubungan Persepsi Perawat Pelaksana Terhadap Penerapan Fungsi Pengorganisasian Yang Dilakukan Oleh Kepala Ruangan Dengan Kinerjanya Diruang Rawat Inap RSUD Koja Jakarta Utara (Doctoral dissertation, Tesis FIK UI, Tidak dipublikasikan).

Rosdahl Caroline Bunker \& Kowalski Mary. 2014. Buku Ajar Keperawatan Dasar Edisi 10 Vol. 1. Ahli bahasa Widiarti, Praptiani \& Mulyaningrum. Jakarta: EGC.

Budiono. (2016). Konsep Dasar Keperawatan. Jakarta : Kementrian Kesehatan Republik Indonesia.

Putra Aryata P.I. (2012). Analisis Penerapan Standar Asuhan Keperawatan di Ruang Rawat Inap Rumah Sakit Umum Provinsi Sulawesi Tenggara. Tesis Universitas Gajah Mada. Yogyakarta. Universitas Gajah Mada. 